\title{
Kersen (Muntingia calabura L.) Leaves Extract as a Novel Alternative Therapy for Hypercholesterolemia
}

\author{
Imaniar Ranti ${ }^{1, *}$, Nur Vickasari $^{2}$, Sukma Maharani Pangestika ${ }^{2}$, Desti Aryani $^{2}$ \\ ${ }^{1}$ Department of Pharmacology, Faculty of Medicine and Health Science, Universitas Muhammadiyah \\ Yogyakarta, Yogyakarta, Indonesia \\ ${ }^{2}$ Medical Science Program, Faculty of Medicine and Health Science, Universitas Muhammadiyah \\ Yogyakarta, Yogyakarta, Indonesia
}

\begin{abstract}
The national market demand for Kopyor coconut is increasing. However, this increase in demand is not matched with sufficient supply. This study aims to determine and describe the farmers motivation in producing Kopyor coconut in Ngagel Village, Pati Regency. The research method used is descriptive. 40 respondents were interviewed using semi-structured questionnaires. Likert scale and Rank Spearman were used to analyse the data. The findings of the study show that the farmers motivation to produce Kopyor coconut are in medium score which mainly focus on fulfilling physiological needs. The farmers motivation to produce Kopyor coconut should be supported and increased as this agriculture product has potency for supporting the farmers economics.
\end{abstract}

\section{Introduction}

Hyperlipidemia is a metabolic disorder characterized by changes in serum lipid and lipoprotein profiles caused by increased concentrations of total cholesterol (TC), low density lipoprotein cholesterol (LDL) with a concurrent decrease in concentrations of high density lipoprotein cholesterol (HDL) [1]. Hypercholesterolemia is a major risk factor for morbidity and death across the world. These variables are recognized to be the primary risk factors for the development and progression of atherosclerosis, as well as related cardiovascular and cerebrovascular disorders [2]. Indonesia has the third highest cardiovascular incidence rate in Asia Pacific, after only Pakistan and the Philippines with the prevalence rates of elevated LDL, TC, and lowered HDL values are known to be 41.9 percent, 35.9 percent, and 22.9 percent, respectively [3]. As a result, more focus should be placed on hypercholesterolemia therapy.

*Corresponding author: imaniarranti@umy.ac.id 
Treatment of hypercholesterolemia without side effects is a challenge for modern medicine. Gastrointestinal and liver problems are among them. Chronic use of these drugs can lead to rhabdomyolysis, which is the most severe adverse effect. This disease is expected to be the major cause of death for almost 24 million people in the year 2030 [4]. A well-known fact is that plant-derived products are safer than synthetic versions and have fewer or no harmful effects on the body. Medicinal compounds derived from plants have accounted for the majority of new compounds discovered in recent years [5]. Natural resources are critical to the economic and well-being of the Indonesian people. There is a need to develop knowledge and technology based on community experience and local wisdom [6]. Kersen (Muntingia calabura L.) leaves are a nice example.

The leaves on kersen fruit are thick, although it is rarely utilized. Some people only eat kersen fruit because they are unaware of the health advantages of kersen leaves, despite scientific evidence demonstrating the numerous health benefits of kersen leaves. Teas made from kersen leaves have been shown to offer anti-inflammatory and antioxidant effects, as well as the ability to boost the immune system. Kersen leaves have been shown to contain possible phytochemical substances such as flavonoids, saponins, and tannins in previous studies [7, 8, 9]. According to Sopandi et al (2019), a combination of kersen fruit juice and lakum leaves might be an option for patients with hyperlipidemia to prevent and avoid additional consequences of high cholesterol [10]. As a result, researchers are curious whether kersen leaves, like kersen fruit or standard medical drug, may enhance lipid levels. The aim of this experiment is to investigate the hypocholesterolemic activity of ethanolic extracts of Kersen (Muntingia calabura L.) leaves in vivo.

\section{Materials and method}

\subsection{Materials}

Kersen (Muntingia calabura L) was collected and identified by Plant Systematics Laboratory, Faculty of Biology, Universitas Gadjah Mada. Male wistar rats (Rattus norvegicus) 3-4 months old weighing 200 grams, total cholesterol test kit reagents, HDL, and LDL with enzymatic method (DiaSysTM, Germany), ethanol 96 percent filter, simvastatin tablet, PTU (Propylthiouracil) 0.01 percent, and high fat diet.

A test animal cage, a place for rats to eat and drink, animal scales, a gastric probe, a syringe, a measuring pipette, a measuring cup, a test tube rack, label paper, markers, a drying cabinet (oven), sieve, pounder, stirrer, filter paper, gauze, funnel, $500 \mathrm{ml}$ Erlenmeyer tube, Vacuum Rotary Evaporator, porcelain dish, storage packaging, powder scale (micolab type 300).

\subsection{Methods}

\subsubsection{Extraction of Kersen (Muntingia calabura L.) Leaves}

The kersen leaves were washed roughly and dried in an oven at $40 \mathrm{oC}$ until the water level reached $10 \%$. The dried leaves were then mixed with a blender. Twenty-five hundred grams of mixed leaves were cultured for three days in $1000 \mathrm{cc}$ of $96 \%$ ethanol. The acquired suspension was filtered into a sterile glass, and the filtrate was filtered into a bottle using Whatman No.1 filter paper until no pasta remained. The ethanol extract of kersen (Muntingia calabura L.) leaves were weighed and then mixed in $100 \mathrm{ml}$ of distilled water to make a stock solution with a concentration of $10 \mathrm{mg} / \mathrm{ml}$. In this investigation, the dosages were $100 \mathrm{mg} / \mathrm{kgBW}, 200 \mathrm{mg} / \mathrm{kgBW}$, and $400 \mathrm{mg} / \mathrm{kgBW}$. 


\subsubsection{Animal Preparation and Feeding Induction}

Thirty male wistar rats (Rattus norvegicus) were adapted for 7 days, and during the adaptation, the experimental rats were fed AIN 76 and drinking distilled water. Quail egg yolks and PTU $0.01 \%$ were combined to create hypercholesterolemic feed. The quail egg yolk to PTU ratio was 2:1. Rats were fed high cholesterol meal induction for 7 days. After adjustment, all blood rats were taken to analyze the presence of lipid profiles (total cholesterol, LDL cholesterol, and HDL cholesterol). Induction of hypercholesterolemia in test animals

\subsubsection{Simvastatin stock solution preparation}

Two simvastatin $10 \mathrm{mg}$ tablets were dissolved in $100 \mathrm{ml}$ of distilled water, yielding a simvastatin stock solution with a concentration of $0.2 \mathrm{mg} / \mathrm{ml}$. In this study, the dosage was $1 \mathrm{mg} / \mathrm{kgBW} /$ day.

\subsubsection{Animal Testing Procedures}

In this study, 35 hypercholesterolemic test animals were divided into five groups, $\mathrm{P} 1$ as a negative control group, P2 as a simvastatin group, P3, P4, P5 as group treated with kersen leaves extract with dosage 100,200 , and $400 \mathrm{mg} / \mathrm{kgBW}$ respectively. The therapy was administered to hypercholesterolemic test animals for 14 days, after which the outcomes were assessed by measuring lipid profile levels.

\subsubsection{Determination of Lipid Profile Level}

Total cholesterol, LDL, and HDL are all components of the lipid profile. Lipid levels were measured three times during the study: post-induction lipid levels following the administration of PTU and high cholesterol diet, and post-treatment day 7 and day 14. The CHOD-PAP technique was used to analyze cholesterol, triglycerides, LDL, and HDL utilizing a diagnostic system kit (Diasys). The lipid profile is analyzed in accordance with the kit's procedures.

\subsubsection{Data analysis}

The statistical methods used were the Shaphiro-Wilk normality test, the Levene homogeneity test, and the ANOVA test to determine the efficacy of kersen leaves ethanol extract on lipid profile levels.

\section{Results and Discussion}

\subsection{Results}

\subsubsection{Lipid Profile of Wistar Male Rats Characteristic}

In this study, the parameters of effective production of hypercholesterolemia in test animals were a rise in LDL and total cholesterol levels coupled by a reduction in HDL levels. Based on data in table 1 , it was discovered that lipid levels altered substantially $(p<0.05)$ before and after the introduction of a high-fat diet and PTU. 
Table 1. Lipid Profile of Wistar Male Rats Characteristic

\begin{tabular}{|c|c|c|c|}
\hline Parameter & Before Induction & After Induction & P \\
\hline LDL & $25,80 \pm 1,06 \mathrm{mg} / \mathrm{dl}$ & $78,14 \pm 0,93 \mathrm{mg} / \mathrm{dl}$ & $<0.05$ \\
\hline Total cholesterol & $77,0 \pm 0,76 \mathrm{mg} / \mathrm{dl}$ & $187,6 \pm 2,01 \mathrm{mg} / \mathrm{dl}$ & $<0.05$ \\
\hline HDL & $64,94 \pm 1,42 \mathrm{mg} / \mathrm{dl}$ & $25,36 \pm 1,30 \mathrm{mg} / \mathrm{dl}$ & $<0.05$ \\
\hline
\end{tabular}

Data were expressed as mean \pm SD (Standard Deviation). Data was significantly different if $p$ value $<0.05$.

\subsubsection{Effect of kersen leaves ethanol extract on lipid profile}

There is a substantial difference in LDL reduction between the control positive group (P2) and the experimental group (P1, P3, P4), but not statistically different from $400 \mathrm{mg} / \mathrm{kgBW}$ kersen leaves ethanol extract group (P5 group) ( $\mathrm{p}>0.05)$ (Figure 1).

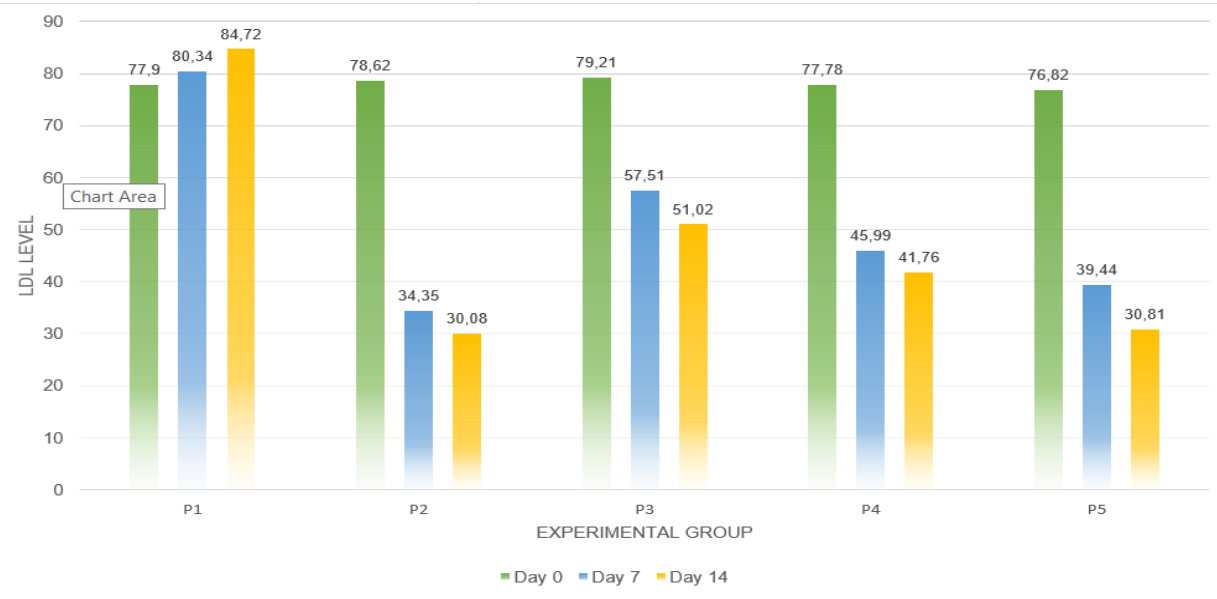

Fig. 1. Effect of kersen leaves ethanol extract on LDL level in vivo

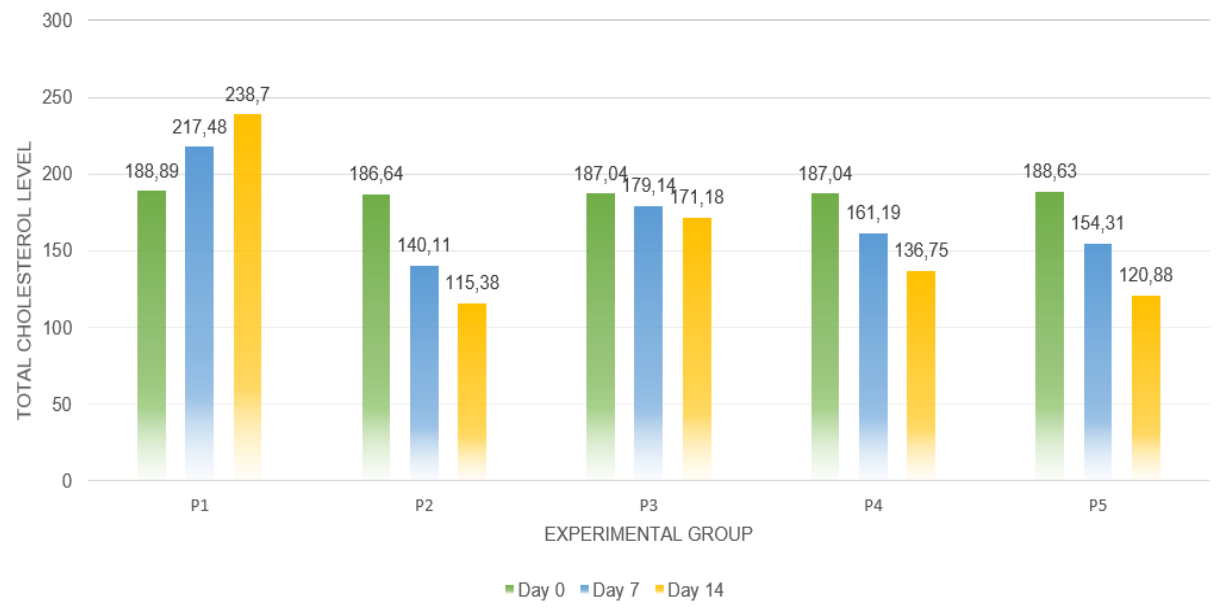

Fig. 2. Effect of kersen leaves ethanol extract on total cholesterol level in vivo 
In the present study, the P2 group had the greatest reduction in total cholesterol on day 7. Whereas, the treatment of group P3, P4, P5 with kersen leaves ethanol extract at 100; $200 ; 400 \mathrm{mg} / \mathrm{kg}$ body weight, did not show a significantly different decrease in total cholesterol (Figure 2).

On the 14th day of post-therapy, total cholesterol readings indicated that the P2 group had the lowest cholesterol levels, but it was not statistically different from the P5 group. This demonstrates that the ethanolic extract of kersen leaves $400 \mathrm{mg} / \mathrm{kgBW}$ is equally effective as simvastatin in lowering total cholesterol levels on the 14th day following treatment as simvastatin (Figure 2).

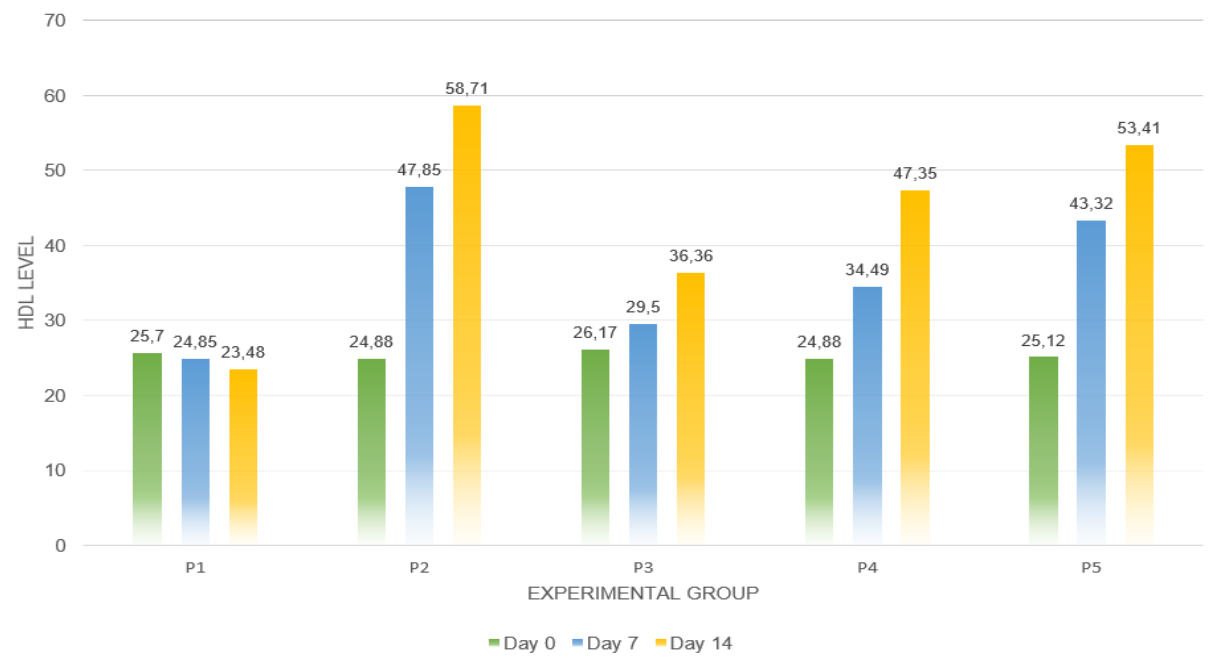

Fig. 3. Effect of kersen leaves ethanol extract on HDL level in vivo

Figure 3 indicates that in the second week of treatment, HDL levels in the positive control group (P2) receiving simvastatin were substantially lower than the other treatment groups $(\mathrm{p}<0.05)$, with the exception of the $400 \mathrm{mg} / \mathrm{kgBW}$ extract group (P5). The study also found that HDL levels in the P2 and P5 group were not substantially different in two times observations $(\mathrm{p}>0.05)$.

\subsection{Discussion}

\subsubsection{Lipid Profile of Wistar Male Rats Characteristic}

In the present study, a hypercholesterolemia test animal model was created by feeding high fat (raw chicken egg yolk) and PTU. The fat and cholesterol content of raw chicken egg yolks influences the rise in lipid levels. Raw chicken egg yolk comprises $60 \%$ lipoprotein, which is composed of $85 \%$ fat and $15 \%$ protein. Lipoprotein fat is made up of $20 \%$ phospholipids (lecithin, phosphatidyl serine), 60\% neutral fat (triglycerides), and 5\% cholesterol. The findings of this study support earlier findings that feeding hypercholesterolemia in the form of egg yolks to rats can dramatically raise their lipid levels $[11,12]$. PTU is an antithyroid chemical that can harm the thyroid gland, preventing thyroid hormone production. Thyroid hormone is important in activating hormone sensitive lipase, which is involved in the process of lipid catabolism in the blood, so that test animals with hypothyroidism have a low catabolism rate, resulting in hypercholesterolemia [13]. 


\subsubsection{Effect of kersen leaves ethanol extract on lipid profile}

According to the findings of this study, kersen leaves extract can lower LDL and total cholesterol levels while increasing HDL levels. The phytochemical content of kersen leaves revealed the presence of flavonoid compounds, tannins, and saponins based on the study's findings $[14,9,15]$. Flavonoids have been shown to inhibit the enzyme 3-hydroxy-3methylglutarylcoenzyme A reductase (HMG-CoA reductase), which reduces cholesterol production, whereas tannins limit fat absorption by reacting with mucosal proteins and intestinal epithelial cells [16]. Tannins can also enhance the process of cholesterol conversion into bile acids and the excretion of bile acids through the stool. Low hepatic cholesterol increases the absorption of cholesterol from the circulation to the liver, which then serves as a precursor of bile acids, lowering blood cholesterol levels [17]. In the positive control group, the efficacy test of kersen leaves extract and simvastatin treatment yielded the same favorable results in reducing blood cholesterol levels of the test animals. Previous research has shown that simvastatin acts by reducing cholesterol production in the liver via the HMG-CoA reductase enzyme. The initial stage in sterol production is mediated by HMG-CoA reductase. Reduced cholesterol production leads proteases to break down SREBP (Sterol Regulatory Element Binding Protein) in the membrane, which is subsequently transferred to the nucleus. The transcription factors will then bind to the LDL receptor gene, increasing the synthesis of LDL receptors. An increase in the number of LDL receptors on hepatocyte cell membranes will lower blood cholesterol levels even more [18].

\section{Conclusion}

Finally, the current findings show that the kersen leaves extract has potential as an antihyperlipidemia. It was found that administering an ethanol extract of kersen leaves at dosages of $100 \mathrm{mg} / \mathrm{kgBW}, 200 \mathrm{mg} / \mathrm{kgBW}$, and $400 \mathrm{mg} / \mathrm{kgBW}$ for 14 days may enhance lipid levels such as LDL, total cholesterol, and HDL in hypercholesterolemic animal models. Giving an ethanol extract of kersen leaves at a dosage of $400 \mathrm{mg} / \mathrm{kgBW} /$ day had the same impact as a positive control in improving blood lipid levels. Future studies might concentrate on the cellular mechanisms of the active compounds found in kersen leaves extract. This can aid in the development of methods to enhance alternative treatment approaches for antihypercholesterolemia and other illnesses.

Acknowledgement. The authors are grateful to research grants of public funds LP3M Universitas Muhammadiyah Yogyakarta for funding.

Conflict of interest. The authors declare no competing interests.

\section{Reference}

1. V. S. Sadik, KM. Geetha, "In-Vivo Antioxidant and Antihyperlipidemic Activity of Syzygium Cerasoideum Extracts In Rats,” Int. J. Pharm. Sci. Res., vol. 10, no. 6, pp. 3062-3072, (2019).

2. I. M. Bencheikh, N., M.Bouhrim, "Antihyperlipidemic and Antioxidant Activities of Flavonoid-Rich Extract of Ziziphus lotus (L.) Lam. Fruits Noureddine,” Appl.Sci, vol. 11, (2021). 
3. Z.-V. Lee et al., "Prevalence of plasma lipid disorders with an emphasis on LDL cholesterol in selected countries in the Asia-Pacific region," Lipids Health Dis., vol. 20, no. 1, p. 33, Apr. (2021).

4. E. Oksal et al., "In vitro and in vivo studies of nanoparticles of chitosan-Pandanus tectorius fruit extract as new alternative treatment for hypercholesterolemia via Scavenger Receptor Class B type 1 pathway," Saudi Pharm. J., vol. 28, no. 10, pp. 1263-1275,(2020).

5. M. Cheurfa and R. Allem, "Study of hypocholesterolemic activity of algerian pistacia lentiscus leaves extracts in vivo," Rev. Bras. Farmacogn., vol. 25, no. 2, pp. 142-144, (2015).

6. Z. Rozaki, O. Wijaya, N. Rahmawati, L. Rahayu, "Farmers' Disaster Mitigation Strategies in Indonesia,” Reviews in Agricutural Science, 9: 178-194. (2021).

7. A. I. Nawir, C. A. N. Afifah, S. Sulandjari, and S. Handajani., "PEMANFAATAN DAUN KERSEN ( Muntingia calabura L . )* Menjadi Teh Herbal," J. tata bogaboga, vol. 10, no. 1, pp. 1-11, (2021).

8. M. 'Azizah, A. M. Handayani, and A. G. Rakhmadevi, "Identifikasi Komponen Senyawa Kimia Daun Kersen (Muntingia calabura) Asal Jember Dengan Metode GCMS,” J. Ilm. Inov., vol. 20, no. 3, pp. 61-63, (2020).

9. A. D. Puspitasari and R. L. Wulandari, "Aktivitas Antioksidan dan Penetapan Kadar Flavonoid Total Ekstrak Etil Asetat Daun Kersen (Muntingia calabura)," J. Pharmascience, vol. 4, no. 2, pp. 167-175, (2017).

10. D. Sopandi, T. R. Saraswati, and ..., "The Effects of Kersen Juice (Mutingia calabura L.) and Lakum Leaf Extract (Cayratia trifolia L.) on Lipid Profile of White Rats (Rattus norvegicus L.) ...,” ... J. Pendidik. Biol., vol. 12, pp. 189-193, (2019).

11. A. Firdaus, "Pengaruh Pemberian Ekstrak Metanol Buah Belimbing Wuluh (Averrhoabilimbi Linn.) Terhadap Kadar Trigliserida Tikus Putih Galur Wistar Hiperlipidemia," vol. 3, (2020).

12. I. Sunnah, E. Kustiyaningsih, and D. Oktianti, "Yellow Pumpkin (Cucurbita maxima D.) Extract As Anti-Hypercolesterolemia," J. Fundam. Appl. Pharm. Sci., vol. 1, no. 2, (2021).

13. S. Sagay, H. E. I. Simbala, and E. De Queljoe, "Uji Aktivitas Antihiperlipidemia Ekstrak Etanol Buah Pinang Yaki (Areca vestiaria) Pada Tikus Putih Jantan Galur Wistar (Rattus norvegicus) yang Diinduksi Pakan Hiperlipidemia," Pharmacon, vol. 8, no. 2, p. 442, (2019).

14. R. D. Pertiwi, Suwaldi, R. Martien, and E. P. Setyowati, "Radical Scavenging Activity and Quercetin Content of Muntingia calabura L. Leaves Extracted by Various Ethanol Concentration," J. Food Pharm. Sci., vol. 8, no. 1, p. 1, (2020).

15. Oktaviani, "Pengaruh Ekstrak Daun Kersen (Muntingia calabura L) terhadap Kolesterol Darah, Soluble ICAM-1 dan Pembentukan Sel Busa pada Tikus dengan Diet Tinggi Lemak dan Kolesterol Effects of Cherry (Muntingia calabura L) Leaf Extract on Blood Cholesterol, Soluble I," J. Kedokt. Brawijaya, vol. 29, no. 3, pp. 202-208, (2016).

16. S. Salvamani, B. Gunasekaran, N. A. Shaharuddin, S. A. Ahmad, and M. Y. Shukor, "Antiartherosclerotic effects of plant flavonoids," Biomed Res. Int., vol. 2014, (2014).

17. A. Asmawati, M. Marianah, A. Yaro, and R. Hendroko Setyobudi, "The potential of Cashew Apple Juice as anti hypercholesterol agent on whistar rats (Rattus norvegicus Berkenhout, 1769)," E3S Web Conf., vol. 226, (2021). 
18. S.-Y. Jiang et al., "Discovery of a potent HMG-CoA reductase degrader that eliminates statin-induced reductase accumulation and lowers cholesterol.," Nat. Commun., vol. 9, no. 1, p. 5138, (Dec. 2018). 